Gold, the Dollar and Watergate 
This page intentionally left blank 


\section{Gold, the Dollar and Watergate}

How a Political and Economic Meltdown was Narrowly Avoided

Onno de Beaufort Wijnholds 


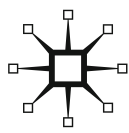

(C) Onno de Beaufort Wijnholds 2015

Softcover reprint of the hardcover 1st edition 2015 978-1-137-47135-2

All rights reserved. No reproduction, copy or transmission of this publication may be made without written permission.

No portion of this publication may be reproduced, copied or transmitted save with written permission or in accordance with the provisions of the Copyright, Designs and Patents Act 1988, or under the terms of any licence permitting limited copying issued by the Copyright Licensing Agency, Saffron House, 6-10 Kirby Street, London EC1N 8TS.

Any person who does any unauthorized act in relation to this publication may be liable to criminal prosecution and civil claims for damages.

The author has asserted his right to be identified as the author of this work in accordance with the Copyright, Designs and Patents Act 1988.

First published 2015 by

PALGRAVE MACMILLAN

Palgrave Macmillan in the UK is an imprint of Macmillan Publishers Limited, registered in England, company number 785998, of Houndmills, Basingstoke, Hampshire RG216XS.

Palgrave Macmillan in the US is a division of St Martin's Press LLC, 175 Fifth Avenue, New York, NY 10010.

Palgrave Macmillan is the global academic imprint of the above companies and has companies and representatives throughout the world.

Palgrave ${ }^{\circledR}$ and Macmillan ${ }^{\circledR}$ are registered trademarks in the United States, the United Kingdom, Europe and other countries

\section{ISBN 978-1-349-50093-2ＩSBN 978-1-137-47136-9 (eBook)}

DOI $10.1057 / 9781137471369$

This book is printed on paper suitable for recycling and made from fully managed and sustained forest sources. Logging, pulping and manufacturing processes are expected to conform to the environmental regulations of the country of origin.

A catalogue record for this book is available from the British Library.

A catalog record for this book is available from the Library of Congress. 


\section{Contents}

List of Figures vii

Preface ix

Acknowledgements $\quad$ xiii

$\begin{array}{lr}\text { Introduction } & 1\end{array}$

Part I Gold 7

1. A unique metal $\quad 7$

2. The gold standard 12

3. Gold loses its luster 16

4. War chest, war loot $\quad 25$

5. Yellow and green $\quad 31$

$\begin{array}{ll}\text { Part II The Dollar } & 37\end{array}$

$\begin{array}{ll}\text { 1. The mighty greenback } & 37\end{array}$

2. From dollar famine to flood 41

3. Working toward a compromise $\quad 50$

4. Change of the guard 62

5. Nixonomics $\quad 68$

$\begin{array}{ll}\text { 6. Showing his dark side } & 75\end{array}$

7. Texas hold 'em $\quad 81$

8. Floating Rudderless $\quad 88$

9. Closing the window 96

10. Monetary diplomacy 107

11. Building an air castle $\quad 125$

12. Nixon triumphant 134

13. Money masters 149

Part III Watergate $\quad 155$

1. Escalation 155

2. War and Oil 158

3. Recycling 164

4. No rest for the wicked 173

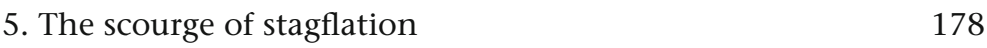


vi Contents

6. A Middle Eastern odyssey 187

7. Down to the wire 194

8. The recession bites 201

9. Nixon's last stand 206

Part IV: Ruin or Revival? $\quad 215$

1. Searching for stability $\quad 215$

2. Stimulate or deflate? 228

3. Talking down the dollar $\quad 237$

4. The dragonslayer 253

$\begin{array}{ll}\text { Notes } & 261\end{array}$

$\begin{array}{ll}\text { Bibliography } & 275\end{array}$

Index 283 


\section{List of Figures}

2.1 U.S. Gold and Official Dollar Claims, 1969-1973 70

3.1 Development of Oil Prices, 1972-1982 162

4.1 U.S. Misery Index, 1969-1984 216

4.2 German Marks per U.S. Dollar, 1969-1984 243 
This page intentionally left blank 


\section{Preface}

On June 17, 1972, I moved to Washington as a young economist released by the Netherlands central bank to be the personal assistant of Pieter Lieftinck, the Dutch executive director at the International Monetary Fund (IMF). The next morning, I woke early and skimmed the Washington Post, a copy of which had been placed in front of my hotel room door. Barely paying any notice to it, I glanced at an item describing a break-in at the headquarters of the Democratic National Committee, in the Watergate building. Soon I was immersed in my work at the IMF, which was experiencing the most challenging period in its almost 30 years' existence. Less than a year before, the link between gold and the dollar had been broken-the first dramatic act in the demise of the exchange rate system constructed at the Bretton Woods Conference in 1944. When I arrived at my new office, further fault lines were appearing in the patched-up monetary framework.

I was fascinated by what was happening in the arena of international finance and had studied the subject intensively both at the University of Amsterdam and at the Netherlands Bank. The IMF was at the center of the international monetary system, and there was no better place to work for someone with a deep interest in how the system worked in practice. I was fortunate in that my patron was the respected dean of the executive board and a former minister of finance who not only had a profound knowledge of how the IMF operated, but who was also greatly experienced in how the worlds of economics and politics interacted. Having a superb mentor was not the only benefit of being an assistant to a board member, but being allowed to sit in on discussions at the highest level was also a useful learning experience. In addition, my contacts with the outstanding fund staff and fellow assistants-later called advisors, reflecting title inflation-were both intellectually stimulating and socially enriching.

To me-an internationalist-the IMF was the most successful large international organization that had ever been established, and many of its executive directors had either been high officials in their home countries or were promising younger persons many of whom would go on to attain very senior positions in their later careers, as was also the case with a number of their assistants whom I befriended. 
In my youthful enthusiasm at living in the power capital of the world, I began to follow American politics closely. Soon Watergate started featuring regularly in the media. I watched the hearings in the Senate and the House Judiciary Committee on television as often as I could. And when the White House tapes were discovered, I began to think, like so many others, that President Nixon would not survive as one revelation followed another. Being slated to return to Europe in October 1974, I often wondered whether I would still be in Washington for the final denouement of the Watergate imbroglio. I was, and I watched the president's resignation speech on my old black-and-white television. When I left the American capital-which I had come to like very much-with my young family, I felt that I had learned a lot both about the inner workings of the IMF and of American politics. What I took from Watergate was not so much amazement at the sordidness as an understanding of how the American system of checks and balances and a free press had made it possible to bring the nightmare to an end.

During the $2 \frac{1}{2}$ years I spent in Washington, three potentially very dangerous crises converged. First was the continuing unraveling of the international exchange rate system and the gambit into a system of general floating without rules; next was Watergate with its potentially disastrous final act; third was the oil shock of late 1973, which pushed the world economy into a steep recession while fueling inflation. What more could a macroeconomist and political junkie wish for? Of course, sitting in a nice office-mine had a view of the Lincoln and Jefferson Memorials_-and enjoying job security, my personal discomfort was limited to the long gas lines after OPEC shocked the world. But to paraphrase Johannes Witteveen, who headed the IMF at the time, it is often best to approach crises with a certain detachment, like a medical doctor who simply cannot worry about his or her patients all the time.

This book is inspired by my precious first years in Washington during an especially turbulent time. It is written as a rolling narrative, spiced with anecdotes and descriptions of the personalities of the main political and money masters of that time. I hope it will to appeal not only to economists, political scientists, and historians but also to those readers who enjoy books of narrative nonfiction about subjects in which they are not experts. Although personal recollections form part of the book, it is based mainly on verifiable sources, such as memoirs, scholarly studies and articles, archives and interviews. Many of the sources I tapped are unknown or little known in the English speaking world, having been written in foreign languages, particularly Dutch, German, and French. Many quotes are taken from Dutch sources, not only because Dutch is 
my native language, but also, to quote Paul Volcker-one of the protagonists of this book-because of "the talent and dedication the Dutch have traditionally supplied to international organizations." ${ }^{1}$ I hope readers will forgive this seemingly chauvinistic use of a quote that I want to place in perspective by mentioning that after serving on the executive board of the IMF from 1994 to 2003, I decided to stay permanently in Washington, D.C., which I now consider my hometown, together with Amsterdam. 
This page intentionally left blank 


\section{Acknowledgements}

This book has benefited greatly from interviews I was able to conduct with a number of senior officials who were intimately involved with the dramatic developments in the international monetary system in the 1970s. Foremost, I wish to thank Johannes Witteveen, managing director of the IMF during its first real crisis, who graciously invited me to his home to answer my questions. I was also fortunate to interview Andrew Crockett, Witteveen's personal assistant at the time, who has since passed away and is sorely missed. Sam Cross, Leo van Houtven and Andre Szasz, from whom I learned much about the politics of economics, all took time to the delve into the past at my request.

My knowledge of the history of the international system has also been enriched over the years through frequent discussions with Jacques Polak and Robert Solomon, both now deceased. Wim Duisenberg, Dolf Kessler, Alexandre Lamfalussy and Emile van Lennep, among others, shared important insights with me at various stages of my career.

Charles Lucas and Paul Shevchenko undertook the unenviable task of reading the manuscript and providing helpful comments. John Coleman and Ian Plenderleith, whom I befriended at the IMF in the early 1970s, kindly answered a few questions about that long-ago period.

I wish to thank Taiba Batool and Rachel Sangster of Palgrave Macmillan, as well as Dane Torbeck for their editorial input. Historical images were promptly provided by the photo archives of the IMF and the Netherlands Bank.

Besides badly needed technical assistance, I much appreciated the interest shown in my work by Aernout and Mariette de Beaufort and Alexandra and Blair Bowie.

Most of all, I am grateful to my wife Chris Nicholson, who not only read the manuscript and improved my grammar and style, but whose never failing support has been crucial for the completion of this project. 